\title{
Analisis Faktor-Faktor Yang Mempengaruhi Perilaku Mahasiswa dalam menggunakan Go-Food di Kota Jambi
}

\author{
$\underline{\text { Hendri }}{ }^{1}$, Mira Saudina ${ }^{2}$, Effiyaldi ${ }^{3}$ \\ Teknik Informatika, Fakultas Ilmu Komputer, Universitas Dinamika Bangsa ${ }^{1}$ \\ Sistem Informasi, Fakultas Imu Komputer, Universitas Dinamika Bangsa ${ }^{2}$ \\ Manajemen, Fakultas Ilmu Manajemen dan Bisnis, Universitas Dinamika Bangsa ${ }^{3}$ \\ Jl. Jendral Sudirman Thehok, Jambi, Indonesia \\ E-mail:hendri@stikom-db.ac.id ${ }^{1}$,mirasaudina97@gmail.com ${ }^{2}$,tanjab67@yahoo.co.id ${ }^{3}$
}

\begin{abstract}
There are several problems occur to students using feature of Go-Food, including weather is raining or excessive heat, does not have a vehicle to buy food that is far from home and the prices listed in the restaurant on feature Go-Food is not appropriate with price after the order. The object in this research was students in Jambi. Data analysis in this study uses two theories, namely The Technology Acceptance Model and Theory of Planned Behavior, as an IBM SPSS statistics V.25.0 research application which helper used for data processing. The purpose of this study was to determine the factors influence student behavior in using feature Go-Food in Jambi city. This study uses a multiple linear regression tool analysis research. Based on the results of the analysis found that from 6 variables in the form of usage attitudes, subjective norms, perceived behavioral control, usability, ease of use does not have a significant effect while price perceptions have a significant effect on student behavior.
\end{abstract}

Keywords: TAM (technology acceptance model), TPB (theory planned behavior), student behavior, Go-Food, analysis.

\begin{abstract}
Abstrak
Ada beberapa hal yang mendorong mahasiswa sehingga menggunakan fitur Go-Food antara lain cuaca yang sedang hujan atau panas yang berlebihan, tidak mempunyai kendaraan untuk membeli makanan yang jaraknya jauh dari rumah serta harga yang tertera di restoran pada fitur Go-Food ada yang tidak sesuai dengan harga setelah di pesan. Objek dalam penelitian ini adalah mahasiswa di kota Jambi. Analisis data pada penelitian ini menggunakan dua teori yaitu Technology Acceptance Model dan Teory Of Planned Behavior.sebagai pembantu penelitian aplikasi IBM SPSS statistics V.25.0 digunakan untuk pengolahan data. Tujuan dari penelitian ini adalah untuk mengetahui faktor-faktor pengaruh perilaku mahasiswa dalam menggunakan fitur Go-Food di kota Jambi. Penelitian ini menggunakan alat penelitian analisis regresi linear berganda. Berdasarkan hasil analisis bahwa dari 6 variabel berupa sikap penggunaan, norma subjektif, kontrol perilaku persepsian, kegunaan, kemudahan penggunaan tidak berpengaruh secara signifikan sedangkan persepsi harga berpengaruh signifikan terhadap perilaku mahasiswa.
\end{abstract}

Kata kunci: TAM (Technology Acceptance Model), TPB (theory planned behavior), perilaku mahasiswa, Go-Food, analisis

\section{Pendahuluan}

Perkembangan teknologi saat ini sangat pesat dan maju. Sejalan dengan kemajuan ilmu pengetahuan dan teknologi, membuat kita berpikir untuk memanfaatkan teknologi tersebut.Tingginya tingkat pertumbuhan penduduk diikuti oleh bertambahnya permintaanmasyarakat akan kebutuhan jasa transportasi. Dari fenomena tersebut lahirlah mobile application yang berfungsi sebagai portal layanan penyedia jasa transportasi. Go-Jek adalah salah satu mobile application yang saat ini sedang naik daun yang menawarkan jasa ojek untuk memenuhi permintaan masyarakat akan kebutuhannya sehari-hari seperti mencari angkutan ojek, dan layanan jasa lainnya[1].

Salah satu fitur layanan yang tersedia pada aplikasi Go-Jek adalah Go-Food, yaitu layanan pesan antar (delivery) yang diberikan perusahan Go-Jek untuk membelikan dan mengantarkan pesanan makanan kepada penggunanya. Layanan tersebut melibatkan 3 (tiga) pihak, yaitu pengguna, restoran, dan pihak ojek. Mekanismenya layanan ini adalah pengguna membuka fitur Go-Foodpada aplikasi Go-Jek sehingga keluar 
daftar restoran dan rumah makan serta harga makanan kemudian pengguna memilih menu makanan yang akan dipesan [2].

PT. Go-Jek Indonesia merupakan pelopor bisnis ojek berbasis teknologi informasi yang didirikan oleh Michaelanglo Maron dan Nadiem Makarim pada tahun 2010 dan mulai beroperasi sejak 2011 [3]. Aplikasi Go-Jek juga menyediakan beberapa pilihan menu seperti Go-Send, Go-Ride, Go-Food, dan lai-lain, dengan adanya beberapa aplikasi pilihan menu tersebut membuat masyarakat dapat memilih kebutuhan mereka. Di dalam layanannya, Go-Food menyediakan berbagai macam referensi dan tipe makanan disertai dengan harga dan gambar dimana konsumen/pemesan dapat dengan bebas dan leluasa untuk memilihnya [4].

Berdasarkan pengamatan yang telah dilakukan oleh penulis, Go-Jek saat ini banyak digunakan oleh berbagai kalangan masyarakat termasuk mahasiswa. Sehingga memudahkan pengguna aplikasi Go-Jek dalam memesan makanan melalui fitur Go-Food. Biasanya mahasiswa dan kalangan masyarakat memesan makanan melalui fitur Go-Food dimana keadaan yang membuat mahasiswa tidak bisa keluar rumah untuk membeli makanan dikarenakan cuaca yang sedang hujan atau sedang dalam keadaan lelah setelah beraktivitas dan keinginan yang ingin makan sesuatu makanan yang tempatnya tidak bisa dijangkau karena tidak mempunyai kendaraan memaksa mereka untuk memesan makanan dengan Go-Food.

Untuk mengetahui perilaku konsumen/mahasiswa tersebut menggunakan dua teori TAM (Technology Acceptance Model) dan TPB (Theory of Planned Behavior). Model Penerimaan Teknologi (Technology Acceptance Model atau TAM) dibangun oleh Davis et al (1989) berdasarkan TRA dan dikhususkan untuk digunakan dibidang sistem informasi untuk memprediksi penerimaan dan penggunaan sistem informasi dipekerjaan individual pemakai [5]. Model ini mengelurkan konstruk sikap (attitude) untuk membuat model lebih sederhana dan untuk menjelaskan niat (intention) dengan lebih baik. TAM menambahkan dua konstruk utama ke dalam model TRA. Dua konstruk utama ini adalah kegunaan persepsian (perceived usefulness) dan kemudahan penggunaan persepsian (perceived ease of use). TAM berargumentasi bahwa penerimaan individual terhadap sistem teknologi informasi ditentukan oleh dua konstruk tersebut.

Teori perilaku terencana ( Theory Of Planned Behavior atau TPB ) merupakan pengembangan lebih lanjut dari Theory Of Reasoned Action (TRA). Icek Ajzen mengembangkan teori TPB dengan menambahkan sebuah konstruk yang belum ada di TRA (Ajzen, 1991). Konstruk ini disebut dengan Kontrol Perilaku Persepsian (Perceived Behavioral Control). Konstruk ini ditambahkan di TPB untuk mengontrol perilaku individual yang dibatasi oleh kekurangan-kekurangan dan keterbatasan-keterbatasan dari kekurangan sumber daya yang digunakan untuk melakukan perilakunya [5]

Pada penelitian ini akan mencari tahu mengenai pengaruh dari faktor sikap penggunaan, norma subjektif, kontrol perilaku persepsian, kegunaan, kemudahan penggunaan dan persepsi harga terhadap perilaku mahasiswa dalam menggunakan fitur Go-Food pada aplikasi Go-Jek di Kota Jambi.

\section{Metodologi}

\subsection{Kerangka Penelitian}

Pada bagian ini akan dijelaskan tahapan-tahapan yang akan dilaksanakan dalam menyelesaikan penelitian ini. Kerangka kerja ini merupakan langkah-langkah yang akan dilakukan dalam penyelesaian masalah yang akan dibahas. Adapun kerangka kerja penelitian yang akan digunakan adalah sebagai berikut:

1. Identifikasi Masalah

Pada tahap ini akan dilakukan identifikasi masalah yang ada untuk menemukan permasalahan pada pengaruh perilaku mahasiswa dalam menggunakan Go-Food di kota Jambi baik dilakukan melalui laporan penelitian ataupun pengamatan langsung.

2. Studi Literatur

Pada tahap ini, penulis melakukan pencarian terhadap landasan-landasan teori yang diperoleh dari berbagai buku, internet, untuk membantu penelitian dalam menemukan landasan teori yang baik mengenai penelitian yang akan dilakukan dan pembuatan laporan.

3. Pengumpulan Data

Metode Pengumpulan data yang dipakai dalam penelitian ini adalah teknikpengumpulan data primer melalui penyebaran kuesioner. Pengumpulan data penelitian dilakukan dengan menyebarkan kuesioner melaluidengan menggunakan google form kepada seluruh sampel yang ditemui. 
4. Analisis Data

Pada tahap ini penulis melakukan analisis terhadap data yang telah dikumpulkan lalu melakukan pengujian hipotesis-hipotesis yang di temui.Setelah data dianalisis langkah selanjutnya melakukan inteprestasi terhadap data dan disusunlah kesimpulan.

5. Pembuatan Laporan

Pada tahap ini dilakukan pembuatan laporan yang disusun berdasarkan hasil penelitian yang telah dilakukan dengan menggunakan data primer atau data sekunder dan menggunakan metode penelitian yang relevan serta terarah pada pokok permasalahan yang ada.

\subsection{Variabel Penelitian}

Variabel yang digunakan dalam penelitian ini terdiri dari dua variabel yaitu variabel dependen dan variabel independen. Variabel dependen dalam penelitian ini berupa perilaku mahasiswa di kota Jambi dalam memanfaatkan Go-Food. Kemudian, variabel independen dalam penelitian ini adalah sikap penggunaan, norma subjektif, kontrol perilaku persepsian, kegunaan, dan kemudahan penggunaan, dan persepsi harga. Keenam variabel ini akan diuji pengaruhnya terhadap perilaku mahasiswa di kota Jambi dalam memanfaatkan Go-Food. Serta manakah dari keenam variabel ini yang paling berpengaruh.

\subsection{Teknik Pengumpulan Data}

Teknik pengumpulan data survei dilakukan dengan menggunakan instrumen kuesioner yang terdiri dari beberapa pernyataan. Responden diminta untuk mengisi pernyataan tersebut kemudian dikembalikan lalu jawaban responden direkam langsung melalui google form. Dalam penelitian survei, jawaban yang diberikan oleh responden sangat bergantung pada pertanyaan dan sifat serta kondisi responden itu sendiri. Untuk menjawab pertanyaan yang diajukan oleh pewawancara sangat dipengaruhi oleh ingatan responden terutama dalam menjawab hal yang berkaitan dengan data angka atau data dan peristiwa yang sudah lewat.

Teknik penarikan sampel dalam penelitian ini adalah dengan menggunakan teknik pengambilan accidental sampling, yaitu siapa saja yang secara kebetulan bertemu dengan peneliti dapat digunakan sebagai sampel, bila dipandang orang yang kebetulan ditemui itu cocok sebagai sumber data. Sampel dalam penelitian ini adalah mahasiswa di kota Jambi yang menggunakan fitur Go-Food dalam aplikasi Go-Jek. Maka untuk menentukan jumlah sampel sebagai berikut [10]:

$$
n=\frac{z^{2} p q}{e^{2}}
$$

Jumlah sampel yang diperlukan (n) dihitung dari nilai kuadrat harga dalam kurve normal untuk simpangan $10 \%$, dengan nilai $1,96(\mathrm{z})$ dikalikan dengan peluang benar $50 \%=0,5(\mathrm{p})$ dan peluang salah $50 \%=0,5$ (q) kemudian dibagi dengan nilai kuadrat dari tingkat kesalahan sampel / sampling error(e)

$$
n=\frac{z^{2} p q}{e^{2}}=\frac{(1,96)^{2}(0,5)(0,5)}{(0,1)^{2}}=96,04
$$

Jadi berdasarkan rumus diatas, sampel yang diambil sebanyak 96,04 orang, untuk memudahkan perhitungan maka dibulatkan menjadi 100 orang.

Kuesioner merupakan teknik pengumpulan data yang dilakukan dengan cara memberi seperangkat pertanyaan atau pernyataan tertulis kepada responden untuk dijawabnya. Kuesioner merupakan teknik pengumpulan data yang efisien bila peneliti tahu dengan pasti variabel yang akan diukur dan tahu apa yang diharapkan dari responden. Dengan menggunakan kuesioner, data langsung dari responden bisa didapatkan. Peneliti menggunakan kuesinoer sebagai alat untuk mengumpulkan data primer dari responden. Kuesioner dalam penelitian ini menggunakan skala likert dengan lima alternatif jawaban yaitu sangat setuju, setuju, netral, tidak setuju,dan sangat tidak setuju [9].

\subsection{Skala Likert}

Skala likert adalah skala yang digunakan untuk mengukur sikap, pendapat, dan persepsi seseorang atau sekelompok orang terhadap suatu kejadian atau keadaan sosial. Dalam penelitian, fenomena sosial ini telah ditetapkan secara spesifik oleh peneliti, yang selanjutnya disebut sebagai variabel penelitian [10]. 
Tabel 1. Pengukuran Skala Likert

\begin{tabular}{lc}
\hline \multicolumn{1}{c}{ Penelitian } & Skor \\
\hline Sangat Setuju & 5 \\
Setuju & 4 \\
Netral & 3 \\
Tidak Setuju & 2 \\
Sangat Tidak Setuju & 1 \\
\hline
\end{tabular}

\subsection{Pengembangan Model Penelitian}

Pada penelitian ini, variabel yang digunakan yaitu sikap penggunaan, norma subjektif, kontrol perilaku persepsian, kegunaan, kemudahan penggunaan [11] dengan ditambahkan Variabel Persepsi Harga [13]. Seperti yang telah dijelaskan sebelumnya pada bagian pendahuluan, tujuan dari penelitian ini untuk mengetahui pengaruh perilaku dari mahasiswa yang menggunakan layanan Go-Food. Untuk Itu, Penulis menggunakan dua teori model penerimaan teknologi (Technology Acceptance Model / TAM) dan teori perilaku terencana (Theory Of Planned Behavior / TPB) dan memodifikasi variabelnya agar sesuai dengan aspek-aspek layanan Go-Food Pada Go-Jek.

\subsection{Hipotesis Penelitian}

Hipotesis yang dibangun pada penelitian ini dapat dilihat pada gambar 1 .

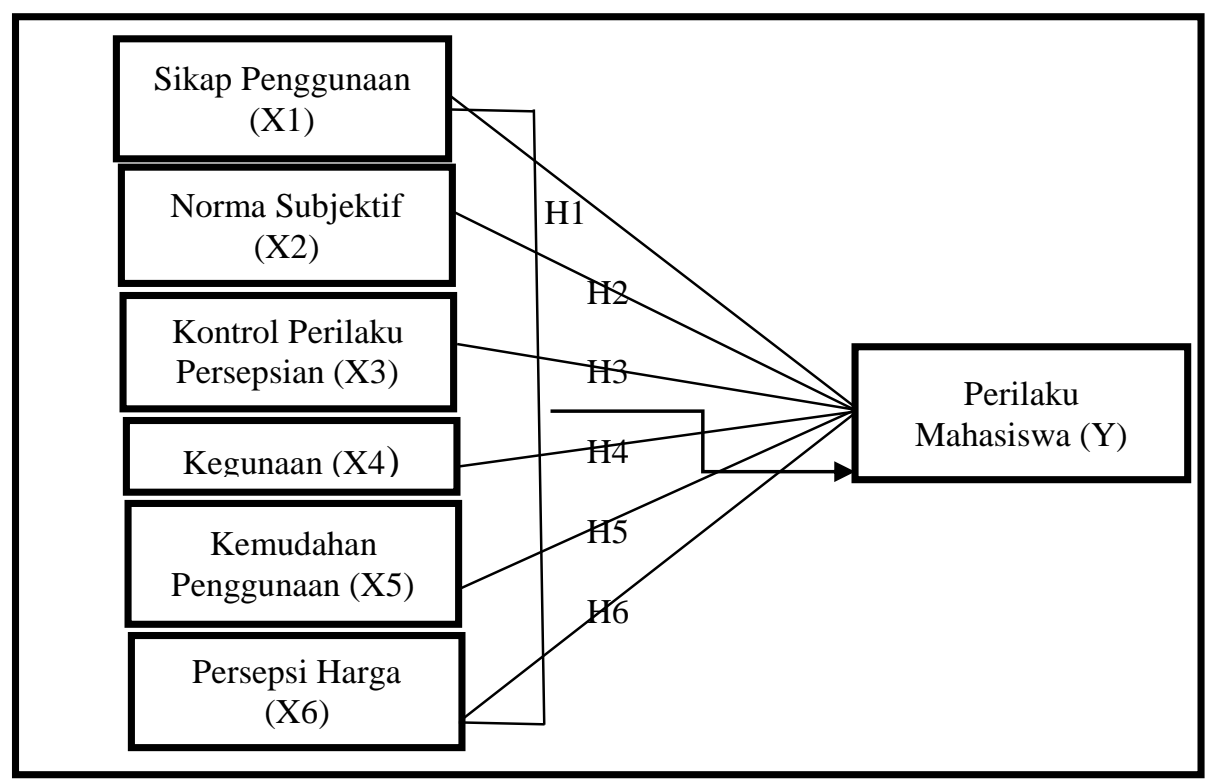

Gambar 1. Hipotesis Penelitian

Hipotesis yang dibangun adalah:

H1 : Sikap penggunaan berpengaruh positif terhadap perilaku mahasiswa di kota Jambi dalam menggunakan Go-Food

H2 : Norma Subjektif berpengaruh positif terhadap perilaku mahasiswa di kota Jambi dalam menggunakan Go-Food

H3 : Kontrol Perilaku Persepsian berpengaruh positif terhadap perilaku mahasiswa di kota Jambi dalam menggunakan Go-Food

H4 : Kegunaan berpengaruh positif terhadap perilaku mahasiswa di kota Jambi dalam menggunakan Go-Food

H5 : KemudahanPengggunaan berpengaruh positif terhadap perilaku mahasiswa di kota Jambi dalam menggunakan Go-Food

H6 : Persepsi Harga berpengaruh positif terhadap perilaku mahasiswa di kota Jambi dalam menggunakan Go-Food 


\section{Hasil dan Pembahasan 3.1 Uji Validitas}

Uji ini dilakukan dengan cara membandingkan angka $r$ hitung dan $r$ tabel. Jika $r$ hitung lebih besar dari $r$ tabel maka item dikatakan valid dan sebaliknya, jika $r$ hitung lebih kecil dari $r$ tabel maka item dikatakan tidak valid.

Tabel 2. Hasil Uji Validitas

\begin{tabular}{ccccc}
\hline No & Variabel & r tabel & r hitung & Keterangan \\
\hline 1 & Butir 1 (X1) & 0,349 & 0,563 & Valid \\
2 & Butir 2 (X1) & 0,349 & 0,883 & Valid \\
3 & Butir 3 (X1) & 0,349 & 0,847 & Valid \\
4 & Butir 4 (X2) & 0,349 & 0,481 & Valid \\
5 & Butir 5 (X2) & 0,349 & 0,546 & Valid \\
6 & Butir 6 (X2) & 0,349 & 0,669 & Valid \\
7 & Butir 7 (X2) & 0,349 & 0,760 & Valid \\
8 & Butir 8 (X3) & 0,349 & 0,741 & Valid \\
9 & Butir 9 (X3) & 0,349 & 0,763 & Valid \\
10 & Butir 10(X3) & 0,349 & 0,694 & Valid \\
11 & Butir 11 (X4) & 0,349 & 0,869 & Valid \\
12 & Butir 12(X4) & 0,349 & 0,812 & Valid \\
13 & Butir 13(X4) & 0,349 & 0,861 & Valid \\
14 & Butir 14 (X5) & 0,349 & 0,895 & Valid \\
15 & Butir 15 (X5) & 0,349 & 0,860 & Valid \\
16 & Butir 16(X5) & 0,349 & 0,821 & Valid \\
17 & Butir 17(X6) & 0,349 & 0,833 & Valid \\
18 & Butir 18 (X6) & 0,349 & 0,890 & Valid \\
19 & Butir 19(X6) & 0,349 & 0,737 & Valid \\
20 & Butir 20(Y) & 0,349 & 0,815 & Valid \\
21 & Butir 21(Y) & 0,349 & 0,846 & Valid \\
22 & Butir 22(Y) & 0,349 & 0,384 & Valid \\
\hline
\end{tabular}

Berdasarkan data yang tercantum pada tabel 1 dapat dijelaskan sebagai berikut :

1. Sikap Penggunaan (X1)

Dari data diatas dapat dilihat bahwa yang termasuk dalam variabel X1 (Sikap Penggunaan) adalah butir 1 sampai 3. Ketiga butir pernyataan tersebut dinyatakan valid, karena semua $r$ hitung yang dihasilkan > 0,349. Jadi, dapat dikatakan bahwa variabel sikap penggunaan dalam penelitian ini valid.

2. Norma Subjektif (X2)

Dari data diatas dapat dilihat bahwa yang termasuk dalam variabel X2 (Norma Subjektif) adalah butir 4 sampai 7. Keempat butir pernyataan tersebut dinyatakan valid, karena semua $r$ hitung yang dihasilkan > 0,349. Jadi, dapat dikatakan bahwa variabel norma subjektif dalam penelitian ini valid.

3. Kontrol Perilaku Persepsian (X3)

Dari data diatas dapat dilihat bahwa yang termasuk dalam variabel X3 (Kontrol Perilaku Persepsian) adalah butir 8 sampai 10. Ketiga butir pernyataan tersebut dinyatakan valid, karena semua $r$ hitung yang dihasilkan > 0,349. Jadi, dapat dikatakan bahwa variabel kontrol perilaku persepsian dalam penelitian ini valid.

4. Kegunaan (X4)

Dari data diatas dapat dilihat bahwa yang termasuk dalam variabel X4 (Kegunaan) adalah butir 11 sampai 13. Ketiga butir pernyataan tersebut dinyatakan valid, karena semua $r$ hitung yang dihasilkan > 0,349. Jadi, dapat dikatakan bahwa variabel kegunaan dalam penelitian ini valid. 
5. Penggunaan (X5)

Dari data diatas dapat dilihat bahwa yang termasuk dalam variabel X5 (Kemudahan Penggunaan) adalah butir 13 sampai 16 . Ketiga butir pernyataan tersebut dinyatakan valid, karena semua $r$ hitung yang dihasilkan> 0,349. Jadi, dapat dikatakan bahwa variabel kemuudahan penggunaan dalam penelitian ini valid.

6. Persespi Harga (X6)

Dari data diatas dapat dilihat bahwa yang termasuk dalam variabel X6 (Persepsi Harga) adalah butir 17 sampai 19. Ketiga butir pernyataan tersebut dinyatakan valid, karena semua $r$ hitung yang dihasilkan $>0,349$. Jadi, dapat dikatakan bahwa variabel persepsi harga dalam penelitian ini valid.

7. Perilaku Mahasiswa (Y)

Dari data diatas dapat dilihat bahwa yang termasuk dalam variabel Y (Perilaku Mahasiswa) adalah butir 20 sampai 22. Ketiga butir pernyataan tersebut dinyatakan valid, karena semua $r$ hitung yang dihasilkan > 0,349. Jadi, dapat dikatakan bahwa variabel perilaku mahasiswa dalam penelitian ini valid.

\subsection{Uji Reliabilitas}

Uji ini dilakukan dengan cara membandingkan angka cronbach alpha dengan ketentuan jika nilai alpha > 0,349 . Artinya jika nilai cronbach alpha yang didapatkan dari hasil perhitungan spss lebih besar dari 0,349 maka disimpulkan kuesioner tersebut reliabel, sebaliknya jika cronbach alpha lebih kecil dari 0,349 maka disimpulkan tidak reliabel.

Tabel 3. Hasil Uji Reliabilitas

\begin{tabular}{cc}
\hline Cronbach's Alpha & N of Items \\
\hline 0,673 & 3 \\
0,461 & 4 \\
0,560 & 3 \\
0,802 & 3 \\
0,819 & 3 \\
0,759 & 3 \\
0,497 & 3 \\
\hline
\end{tabular}

Dilihat dari tabel bahwa di dapat cronbach's alpha dari masing-masing item bahwa cronbach's alpha lebih besar dari $r$ tabel yaitu 0,349 .

\subsection{Uji Normalitas}

Setelah melakukan uji validitas dan reliabilitas maka langkah selanjutnya adalah melakukan uji normalitas untuk menguji apakah nilai residual yang dihasilkan regresi terdistribusi secara normal atau tidak. Pada penelitian ini, uji normalitas dilakukan denggan metode grafik, dari grafik tersebut dapat dilihat penyebaran data pada sumber diagonal pada grafik $\mathrm{P}$ - P plot of regression standarized residual, seperti pada gambar: 


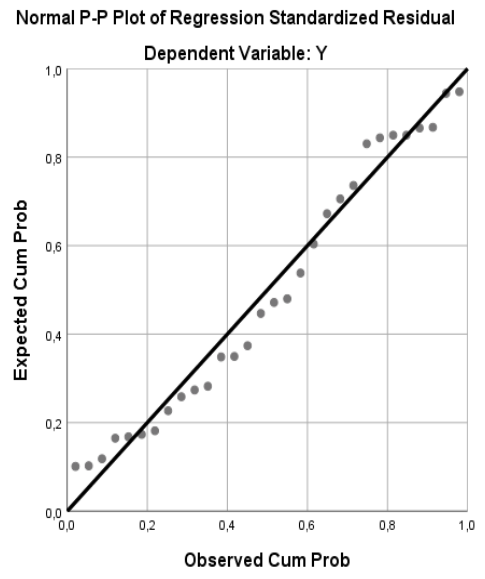

Gambar 2 Normalitas Grafik Normal P - P plot

Dari grafik tersebut dapat diketahui bahwa titik-titik menyebar disekitar garis dan mengikuti arah garis diagonal, maka data terdistribusi dengan normal dan model regresi telah memenuhi asumsi normalitas.

\subsection{Uji Multikolinearitas}

Uji multikolinieritas bertujuan untuk menguji apakah model regrei ditemukan adanya korelasi atau hubungan antar variabel bebas (independen) dengan melihat nilai Tolerance dan VIF (Variant Inflation Factor) pada model regresi, standar nilai VIF agar dikategorikan bebas dari multikolinearitas cukup beragam namun 2 nilai standar yang sering dipakai sebagai batasan adalah 5 atau 10, maka peneliti memakai nilai VIF 10. Jika tolerance lebih dari 0,1 dan VIF kurang dari 10 maka tidak terjadi multikolinieritas. Jika variabel bebas saling berkolerasi, maka variabel-variabel ini tidak ortogonal yaitu variabel bebas yang nilai korelasi antar sesama variabel bebas dengan nol. Hasil dari uji multikolinearitas dapat dilihat pada tabel berikut.

Tabel 4. Hasil Uji Multikolinearitas

\begin{tabular}{cccc}
\hline Variabel & Tolerance & $\begin{array}{c}\text { VIF(Variant Inflation } \\
\text { Factor) }\end{array}$ & Keterangan \\
\hline X1 & $0,798>0,10$ & $1,253<10,00$ & Tidak terjadi Multikolinearitas \\
X2 & $0,575>0,10$ & $1,740<10,00$ & Tidak terjadi Multikolinearitas \\
X3 & $0,847>0,10$ & $1,181<10,00$ & Tidak terjadi Multikolinearitas \\
X4 & $0,401>0,10$ & $2,494<10,00$ & Tidak terjadi Multikolinearitas \\
X5 & $0,433>0,10$ & $2,311<10,00$ & Tidak terjadi Multikolinearitas \\
X6 & $0,602>0,10$ & $1,660<10,00$ & Tidak terjadi Multikolinearitas \\
\hline
\end{tabular}

Dari tabel diatas dapat diketahui bahwa nilai Tolerance dari keenam variabel independen lebih dari 0,1 dan nilai VIF kurang dari 10, jadi disimpulkan bahwa tidak terjadi masalah multikolinieritas pada model regresi.

\subsection{Uji Autokorelasi}

Uji autokorelasi dalam penelitian ini menggunakan metode uji Durbin Watson. Telah dibahas pada bab sebelumnya, bahwa uji autokorelasi digunakan untuk mengetahui ada atau tidaknya penyimpangan asumsi klasik autokorelasi variabel yang ada di dalam model prediksi dengan perubahan waktu. Selanjutnya, nilai hasil uji autokorelasi dalam penelitian ini akan dibandingkan dengan nilai durbin watson pada tabel durbin watson dengan signifikansi 5\% atau 0,05. Data dikatakan bebas autokorelasi jika nilai durbin watson $>$ nilai du. Nilai dL dan dU dapat dilihat pada tabel Durbin-Watson pada signifikansi 0,05, n=30 dan k=6 ( $\mathrm{n}$ adalah jumlah data dan $\mathrm{k}$ adalah jumlah variabel independen). Didapat $\mathrm{dL}=0,998 \mathrm{dan} \mathrm{dU}=1,931$. Output dari uji autokorelasi dengan menggunakan SPSS pada penelitian ini dapat dilihat pada tabel berikut. 
Tabel 5. Hasil Uji Autokorelasi

\begin{tabular}{ll}
\hline Model & Durbin-Watson \\
\hline 1 & 1,965 \\
\hline
\end{tabular}

Berdasarkan hasil uji durbin watson diatas diperoleh nilai durbin watson sebesar 1,965 > 1,931, sehingga dapat diambil kesimpulan bahwa data dalam penelitian ini terbebas dari masalah autokorelasi.

\subsection{Uji Heterokedastisitas}

Uji heteroskedastisitas pada penelitian ini menggunakan uji koefisien korelasi Glejser Test. Metode uji Glejser Test yaitu meregresikan nilai absolute residual terhadap variabel independen. Pengujian ini menggunakan tingkat signifikan 0,05 dengan uji 2 sisi. Taraf signifikan itu sendiri ada 2 macam 0,01 dan 0,05 , tidak ada ketentuan baku yang mengatur harus menggunakan yang mana. Semua itu tergantung pada peneliti dan penelitian itu sendiri namun banyak peneliti terdahulu memakai taraf signifikan 0,05 . Hasil dari uji heteroskedastisitas dapat dilihat pada tabel berikut.

Tabel 6. Hasil Uji Heteroskedastisitas Glejser Test

\begin{tabular}{ccl}
\hline Variabel & Nilai Signifikansi & \multicolumn{1}{c}{ Keterangan } \\
\hline X1 & $0,094>0,05$ & Tidak terjadi heteroskedastisitas \\
X2 & $0,840>0,05$ & Tidak terjadi heteroskedastisitas \\
X3 & $0,532>0,05$ & Tidak terjadi heteroskedastisitas \\
X4 & $0,769>0,05$ & Tidak terjadi heteroskedastisitas \\
X5 & $0,107>0,05$ & Tidak terjadi heteroskedastisitas \\
X6 & $0,512>0,05$ & Tidak terjadi heteroskedastisitas \\
\hline
\end{tabular}

Dari hasil uji heteroskedastisitas Glejser Test yang telah dilakukan, didapatkan bahwa nilai signifikansi dari tiap variabel memenuhi syarat.

\subsection{Uji Linearitas}

Metode pengambilan keputusan untuk uji linieritas yaitu jika signifikansi pada linearity > 0,05 maka hubungan antara dua variabel dinyatakan linear. Tujuan ujilinearitas digunakan untuk mengetahui apakah kedua variabel mempunyai hubungan yang linear secara signifikan atau tidak. Output dari uji linearitas dengan menggunakan SPSS pada penelitian ini dapat dilihat pada tabel berikut :

Tabel 7. Hasil Uji Linearitas

\begin{tabular}{ccc}
\hline Hubungan Variabel & Berdasarkan Nilai Sig & Keterangan \\
\hline $\mathrm{Y} * \mathrm{X} 1$ & $0,481>0,05$ & Linear secara signifikan \\
$\mathrm{Y} * \mathrm{X} 2$ & $0,752>0,05$ & Linear secara signifikan \\
$\mathrm{Y} * \mathrm{X} 3$ & $0,120>0,05$ & Linear secara signifikan \\
$\mathrm{Y} * \mathrm{X} 4$ & $0,942>0,05$ & Linear secara signifikan \\
$\mathrm{Y} * \mathrm{X} 5$ & $0,987>0,05$ & Linear secara signifikan \\
$\mathrm{Y} * \mathrm{X} 6$ & $0,531>0,05$ & Linear secara signifikan \\
\hline
\end{tabular}

Data diatas diuraikan sebagai berikut :

1. Variabel Sikap Penggunaan* Variabel Perilaku Mahasiswa

Dari tabel diatas dapat diketahui signifikansi pada Linearity sebesar 0,481. Dikarenakan signifikansi lebih dari 0,05 jadi hubungan antara variabel sikap pengggunaan dengan variabel perilaku mahasiswa dinyatakan linear. 
2. Variabel Norma Subjektif* Variabel Perilaku Mahasiswa

Dari table diatas dapat diketahui signifikansi pada Linearity sebesar 0,752. Dikarenakan signifikansi lebih dari 0,05 jadi hubungan antara variabel norma subjektif dengan variabel perilaku mahasiswa dinyatakan linear.

3. Variabel Kontrol Perilaku Persepsian* Variabel Perilaku Mahasiswa

Dari tabel diatas dapat diketahui signifikansi pada Linearity sebesar 0,120. Dikarenakan signifikansi lebih dari 0,05 jadi hubungan antara variabel kontrol perilaku persepsian dengan variabel perilaku mahasiswa dinyatakan linear.

4. Variabel Kegunaan* Variabel Perilaku Mahasiswa

Dari tabel diatas dapat diketahui signifikansi pada Linearity sebesar 0,942. Dikarenakan signifikansi lebih dari 0,05 jadi hubungan antara variabel kegunaan dengan variabel perilaku mahasiswa dinyatakan linear.

5. Variabel Kemudahan Penggunaan * Variabel Perilaku Mahasiswa

Dari tabel diatas dapat diketahui signifikansi pada Linearity sebesar 0,987. Dikarenakan signifikansi lebih dari 0,05 jadi hubungan antara variabel kemudahan penggunaan dengan variabel perilaku mahasiswa dinyatakan linear.

6. Variabel Persepsi Harga * Variabel Perilaku Mahasiswa

Dari tabel diatas dapat diketahui signifikansi pada Linearity sebesar 0,531. Dikarenakan signifikansi lebih dari 0,05 jadi hubungan antara variabel persepsi harga dengan variabel perilaku mahasiswa dinyatakan linear.

\subsection{Uji Regresi Linear Berganda}

Analisis regresi linear berganda merupakan hubungan secara linear antara dua atau lebih variabel independen dengan variabel dependen. Regresi dilain pihak menjelaskan pengaruh satu variabel atau lebih disebut variabel independen terhadap variabel lain disebut variabel dependen.Analisis yang digunakan dalam penelitian ini adalah analisis regresi berganda. Model regresi yang digunakan dalam penelitian ini adalah sebagai berikut:

$\boldsymbol{Y}=\boldsymbol{a}+\boldsymbol{b} \times 1+\boldsymbol{b} 2 \times 2+\boldsymbol{b} 3 \times 3+\boldsymbol{b} 4 \times 4+\boldsymbol{b} 5 \times 5+\boldsymbol{b} \times 6+\boldsymbol{e}$

Dimana Y adalah Perilaku mahasiswa, a adalah Konstanta, $b 1, b 2, b 3, b 4, b 5, b 6$ adalah Koefisien Regresi, $X 1$ adalah Sikap Penggunaan, $X 2$ adalah Norma Subjektif, $X 3$ adalah Kontrol Perilaku Persepsian, $X 4$ adalah Kegunaan, $X 5$ adalah Kemudahan Penggunaan, $X 6$ adalah Persepsi Harga dan e adalah Error.

Hasil analisis regresi linear berganda dalam penelitian ini dapat dilihat pada tabel pada tabel berikut :

Tabel 8. Hasil Uji Regresi

\begin{tabular}{ccc}
\hline \multirow{2}{*}{ Model } & \multicolumn{2}{c}{ Unstandardized Coefficients } \\
\cline { 2 - 3 } & B & Std. Error \\
\hline (Constant) & 2,9 & 1,494 \\
X1 & 0,533 & 0,086 \\
X2 & 0,074 & 0,077 \\
X3 & $-0,085$ & 0,072 \\
X4 & 0,099 & 0,115 \\
X5 & $-0,049$ & 0,118 \\
X6 & 0,185 & 0,088 \\
\hline
\end{tabular}


Berdasarkan hasil output spss.25 diatas dapat disimpulkan bahwapersamaan regresi dalam penelitian ini berupa :

$\mathrm{Y}=2,900+0,533 X 1+0,074 X 2-0,085 X 3+0,099 X 4-0,049 X 5+0,185 X 6+\mathrm{e}$

\subsection{Koefisien Determinasi}

Uji determinasi dalam penelitian ini bertujuan untuk mengetahui persentase sumbangan pengaruh variabel independen terhadap variabel dependen. Koefisien determinasi pada intinya mengukur seberapa jauh kemampuan variabel independen dalam mempengaruhi variabel dependen. Koefisien determinasi dapat diperoleh dengan cara mengkuadratkan koefisien korelasi atau $R$ Squared (R2).

Tabel 9. Hasil Koefisien Determinasi

\begin{tabular}{cc}
\hline Model & R Square \\
\hline 1 & 0,519 \\
\hline
\end{tabular}

Berdasarkan hasil uji determinasi diatas didapatkan nilai Adjusted R Square sebesar 0,519, sehingga dapat diambil kesimpulan bahwa Sikap Penggunaan (X1), Norma Subjektif (X2), Kontrol Perilaku Persepsian (X3), Kegunaan (X4), Kemudahan Penggunaan (X5), serta Persepsi harga (x6) mempengaruhi Perilaku Mahasiswa (Y) sebesar 51,9\%. Sedangkan, sisanya $(48,1 \%)$ dipengaruhi oleh variabel lain diluar dari penelitian ini.

\subsection{Uji T-Statistik}

Analisis pengujian individual atau parsial (Uji t) telah dijelaskan pada bab sebelumnya. Pengujian ini diperlukan untuk mengetahui bahwa variabel independen secara parsial mempunyai pengaruh yang signifikan terhadap variabel dependen. Pengambilan keputusan dalam uji ini didasarkan pada tingkat signifikansi sebesar 0,05 dan t tabel sebesar 1,98552. Hasil uji T dapat dilihat pada tabel berikut ini :

Tabel 10. Hasil Uji T Statistik

\begin{tabular}{ccc}
\hline Variabel & T & Sig \\
Konstanta & 1,941 & 0,055 \\
\hline X1 & 6,198 & 0,000 \\
X2 & 0,961 & 0,339 \\
X3 & $-1,169$ & 0,245 \\
X4 & 0,860 & 0,392 \\
X5 & $-0,416$ & 0,678 \\
X6 & 2,104 & 0,038 \\
\hline
\end{tabular}

Dari data diatas, peneliti dapat memberikan analisa hasil uji hipotesis sebagai berikut :

1. Sikap Penggunaan (X1) menghasilkan nilai t hitung sebesar 6,198 > 1,985 dan nilai signifikansi sebesar $0,000<0,05$, sehingga dapat diambil kesimpulan bahwa Sikap Penggunaan (X1) berpengaruh positif signifikan terhadap perilaku mahasiswa $(\mathrm{Y})$.

2. Norma Subjektif (X2) menghasilkan nilai t hitung sebesar 0,961 < 1,985 dan nilai signifikansi sebesar 0,339>0,05, sehingga dapat diambil kesimpulan bahwa Norma Subjektif (X2) berpengaruh negatif tidak signifikan terhadap perilaku mahasiswa $(\mathrm{Y})$.

3. Kontrol Perilaku Persepsian (X3) menghasilkan nilai t hitung sebesar $-1,169<1,985$ dan nilai signifikansi sebesar 0,245> 0,05, sehingga dapat diambil kesimpulan bahwa Kontrol Perilaku Persepsian (X3) berpengaruh negatif tidak signifikan terhadap Perilaku mahasiswa (Y).

4. Kegunaan (X4) menghasilkan nilai t hitung sebesar $0,860<1,985$ dan nilai signifikansi sebesar 0,392>0,05, sehingga dapat diambil kesimpulan bahwa Kegunaan (X4) berpengaruh negatif tidak signifikan terhadap perilaku mahasiswa (Y). 
5. Kemudahan Penggunaan (X5) menghasilkan nilai t hitung sebesar $-0,416<1,985$ dan nilai signifikansi sebesar 0,678>0,05, sehingga dapat diambil kesimpulan bahwa Kemudahan Penggunaan (X5) berpengaruh negatif tidak signifikan terhadap perilaku mahasiswa (Y).

6. Persepsi Harga (X6) menghasilkan nilai t hitung sebesar 2,104 > 1,985 dan nilai signifikansi sebesar 0,038 < 0,05, sehingga dapat diambil kesimpulan bahwa Kemudahan Penggunaan (X5) berpengaruh positif signifikan terhadap perilaku mahasiswa $(\mathrm{Y})$.

\subsection{Uji F-Statistik}

Uji F atau dikenal sebagai uji serentak bertujuan untuk mengetahui bagaimanakah pengaruh semua variabel independen dalam suatu penelitian secara bersama-sama terhadap variabel dependen. Jika hasilnya signifikan maka model bisa digunakan untuk prediksi/ peramalan dalam penelitian. Uji F dapat dilakukan dengan membandingkan tingkat signifikansi, jika kurang dari 0,05, maka bisa dikatakan bahwa variabel independen dalam penelitian ini signifikan. Hasil uji $\mathrm{F}$ pada penelitian ini dapat dilihat pada tabel berikut ini :

Tabel 11. Hasil Uji F

\begin{tabular}{lcl}
\hline \multicolumn{1}{c}{ Model } & F & Sig \\
\hline Regression & 16,735 & 0,000 \\
Residual & & \\
Total & & \\
\hline
\end{tabular}

Dari data hasil output spss diatas diperoleh nilai signifikansi sebesar $0,000<0,05$, maka dapat ditarik kesimpulan bahwa Sikap Penggunaan (X1), Norma Subjektif (X2), Kontrol Perilaku Persepsian (X3), Kegunaan (X4), Kemudahan Penggunaan (X5) serta Persepsi Harga (X6) secara bersama-sama berpengaruh signifikan terhadap Perilaku Mahasiswa (Y).

\subsection{Hasil Uji Hipotesis}

H1: Sikap penggunaan berpengaruh positif terhadap perilaku mahasiswa kota Jambi dalam menggunakan Go-Food.

Berdasarkan data yang diolah sikap penggunaan memberikan hasil t hitung sebesar 6,198>1,985 dan nilai signifikansi sebesar $0,000<0,05$. Sehingga dapat ditarik kesimpulan bahwa sikap penggunaan berpengaruh positif dan signifikan terhadap perilaku mahasiswa. Hal ini serupa dengan penelitian [11] yang menunjukkan sikap penggunaan memberikan pengaruh secara positif terhadap perilaku mahasiswa.

H2: Norma Subjektif berpengaruh poositif terhadap perilaku mahasiswa kota Jambi dalam menggunakan Go-Food

Berdasarkan data yang diolah norma subjektif memberikan hasil t hitung sebesar sebesar $0.961<1,985$ dan nilai signifikansi sebesar 0,339>0,05. Sehingga dapat ditarik kesimpulan bahwa norma subjektif berpengaruh negatif dan tidak signifikan terhadap perilaku mahasiswa. Hal ini serupa dengan penelitian [12] yang menunjukkan norma subjektif memberikan pengaruh secara negatif terhadap perilaku mahasiswa.

H3: Kontrol Perilaku Persepsian berpengaruh positif terhadap perilaku mahasiswa kota Jambi dalam menggunakan Go-Food

Berdasarkan data yang diolah kontrol perilaku persepsian memberikan hasil t hitung sebesar sebesar -1,169 $<1,985$ dan nilai signifikansi sebesar 0,245> 0,05. Sehingga dapat ditarik kesimpulan kontrol perilaku persepsian berpengaruh negatif dan tidak signifikan terhadap pemanfaatan layanan Go-Food. Hal ini serupa dengan penelitian [11] yang menunjukan kontrol perilaku persepsian memberikan pengaruh secara negatif terhadap perilaku mahasiswa. 
H4: Kegunaan berpengaruh positif terhadap perilaku mahasiswa kota Jambi dalam menggunakan Go-Food

Berdasarkan data yang diolah variabel kegunaan memberikan hasil t hitung sebesar sebesar 0,860< 1,985 dan nilai signifikansi sebesar 0,392 >0,05. Sehingga dapat ditarik kesimpulan bahwa kegunaan berpengaruh negatif dan tidak signifikan terhadap pemanfaatan layanan Go-Food. Hal ini serupa dengan penelitian [11] yang menunjukan memang kegunaan memberikan pengaruh secara negatif terhadap perilaku mahasiswa.

H5: Kemudahan Penggunaan berpengaruh positif terhadap perilaku mahasiswa Jambi dalam menggunakan Go-Food

Berdasarkan data yang diolah variabel kemudahan penggunaan memberikan hasil t hitung sebesar sebesar $-0,416<1,985$ dan nilai signifikansi sebesar $0,678>0,05$. Sehingga dapat ditarik kesimpulan bahwa kemudahan penggunaan berpengaruh negatif dan tidak signifikan terhadap perilaku mahasiswa. Hal ini serupa dengan penelitian [11] yang menunjukan memang kemudahan penggunaan memberikan pengaruh secara negatif terhadap perilaku mahasiswa.

H6: Persepsi Harga berpengaruh positif terhadap perilaku mahasiswa kota Jambi dalam menggunakan GoFood

Berdasarkan data yang diolah variabel persepsi harga memberikan hasil t hitung sebesar sebesar 2,104 > 1,985 dan nilai signifikansi sebesar 0,038< 0,05 Sehingga dapat ditarik kesimpulan bahwa persepsi harga berpengaruh positif dan signifikan terhadap perilaku mahasiswa. Hal ini serupa dengan penelitian[13] yang menunjukan memang persepsi harga memberikan pengaruh secara positif terhadap perilaku mahasiswa.

\section{Kesimpulan}

Analisis terhadap faktor-faktor yang mempengaruhi perilaku mahasiswa dalam menggunakan Go-Food di kota Jambi menghasilkan pernyataan bahwa Sikap penggunaan (X1) dan Persepsi Harga (X6) berpengaruh dan signifikan terhadap perilaku mahasiswa dalam menggunakan Go-Food, namun Norma subjektif (X2), Kontrol perilaku persepsian (X3), Kegunaan (X4), serta Kemudahan penggunaan (X5) tidak berpengaruh dan tidak signifikan terhadap perilaku mahasiswa dalam menggunakan Go-Food. Sehingga dapat di tarik kesimpulan bahwa seluruh hipotesis dalam penelitian ini diterima.

\section{Daftar Rujukan}

[1] J. Susanto, “Analisis Faktor-Faktor yang Mempengaruhi Adopsi Aplikasi GO-JEK Sebagai Penyedia Jasa Transportasi di Surabaya," vol. 60219, 2016.

[2] A. A. Yusufin, "Transaksi Jual Beli Melalui Jasa Go Food Dalam Perspektif Hukum Islam,” 2018.

[3] H. Al Rasyid, "Pengaruh Kualitas Layanan Dan Pemanfaatan Teknologi Terhadap Kepuasan Dan Loyalitas Pelanggan Go-Jek," J. Ecodemica J. Ekon. Manajemen, dan Bisnis, vol. 1, no. 2, pp. 210223, 2017.

[4] E. Hartati and Yulistia, “Analisis Pengguna Layanan Go-Jek Dikota Palembang,” vol. 8, pp. 101106, 2017.

[5] Jogiyanto and W. Abdillah, Sistem Tatakelola Teknologi Informasi. Yogyakarta: Andi, 2011.

[6] R. R. F. Mu'izz, "Kualitas Aplikasi Mobile Go Jek Di Kalangan Masyarakat Kota Surabaya ( Study Deskriptif Kualitas dan Kesuksesan Sistem Teknologi Informasi Aplikasi Go Jek ),” 2016.

[7] M. Nuruddin, “Analisis Hukum Islam Terhadap Praktik Pemesanan Makanan Melalui Jasa Online Go - F Jek Oo D Pada Aplikasi Go - Di Kota Surabaya," 2018.

[8] R. Tumuwe, M. Damis, and T. Mulianti, "Pengguna Ojek Online Di Kalangan Mahasiswa Universitas Sam Ratulangi Manado,” no. 21, 2018.

[9] H. Firdaus, "Analisis Pengaruh Kepuasan Konsumen, Kualitas Layanan dan Kepercayaan Terhadap Loyalitas Pelanggan Dalam Menggunakan Jasa Go-Jek Pada Masyarakat Kepahlawanan Kota Palembang," 2017.

[10] J. F. Alkhair, "Determinan Perilaku Masyarakat Menggunakan Go-Food Perspektif Ekonomi Islam Di Kelurahan Sindhoarjo Daerah Istimewa Yogyakarta," 2018.

[11] R. Setyaningsih, "Analisis Faktor-Faktor Yang Mempengaruhi Pemanfaatan Go-Food (Studi Kasus Pada Mahasiswa UII), 2018.

[12] I. Mahendra and N. Septiany, "Analisa Faktor-Faktor Yang Mempengaruhi Minat Mahasiswa 
Dalam Penggunaan Aplikasi Grab ( Studi Kasus : Mahasiswa Stmik Nusa Mandiri Jakarta ),” vol. 4, no. 1, pp. 9-16, 2018.

[13] A. Zahra, "Pengaruh Kualitas Pelayanan, Persepsi Harga, Dan Citra Merek Terhadap Kepuasan Pelanggan Pengguna Jasa Transportasi Ojek Online (Studi Pada Pelanggan Go-Jek Di KotaYogyakarta)," 2017. 